Fall 2015

\title{
Influencing the Influencers
}

Mark Womack

Cedarville University, womackm@cedarville.edu

Follow this and additional works at: https://digitalcommons.cedarville.edu/staff_publications

Part of the Higher Education Commons

\section{Recommended Citation}

Womack, Mark, "Influencing the Influencers" (2015). Staff Publications. 55.

https://digitalcommons.cedarville.edu/staff_publications/55

This Article is brought to you for free and open access by DigitalCommons@Cedarville, a service of the Centennial Library. It has been accepted for inclusion in Staff

Publications by an authorized administrator of DigitalCommons@Cedarville. For more information, please contact digitalcommons@cedarville.edu. 



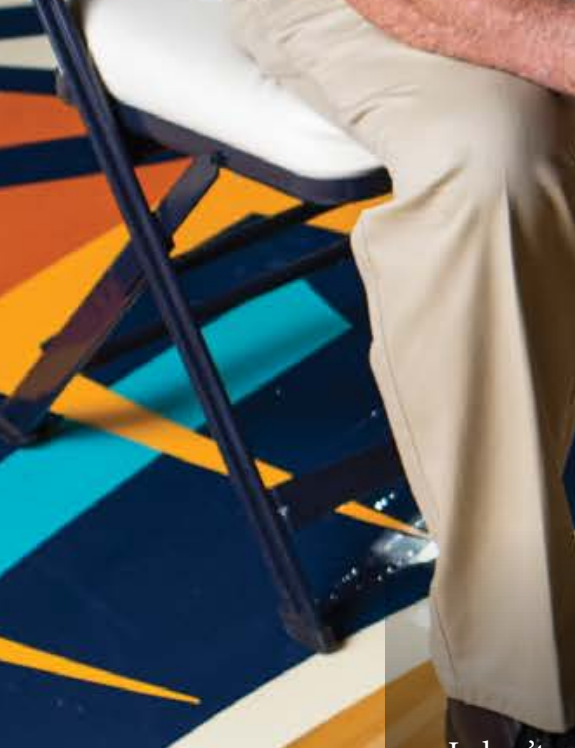

I don't personally know many people who have a building named after them. I doubt anyone sets out in life with that honor as one of their ultimate goals.

However, I do know this ... If your name is on a building, you've influenced people in some incredible fashion. Period.

Such people like Don Callan, or "Coach" to many of us, are difference-makers in their own special way.

And, so reads the plaque upon entering the Callan Athletic Center, which I see nearly every day upon heading to my office:

"In grateful recognition of the Christian testimony and faithful service of Donald E. Callan as a coach, missions leader, athletic director, professor, department chair, and dean at Cedarville University." by Mark Womack '82

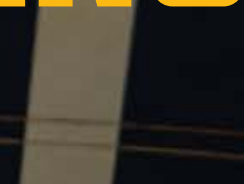


I was able to catch up with Coach, who is supposedly retired, late this summer - one day before he was leaving on yet another sports ministry trip.

"I always knew what I was going to do in life," he proclaimed. "Even though I didn't know where I would be, God had put me into athletics to minister.

"After 50 years at Cedarville, I did everything I wanted to do in my life. I just wanted to provide a good example of following Christ and being a witness for Him throughout the world. I've been able to do that."

As a young man, Callan himself was the recipient of the "teach others also" command by his former coach and influencer, the late Don Odle at Taylor University.

"Don Odle had the biggest impact on me, and my life has demonstrated that. Everyone that knew us said I was a clone.

"He may not have been the best coach, but he was the most influential man I was ever around because he was so committed to reaching the lost with the Gospel of Christ."

One three-month trip through East Asia with Odle and the Ventures for Victory basketball team was all it took.

"It was the 1950s, and I think we were the first team to ever use sports for evangelism," he recalled. "It's where I caught the real vision of ministry."

That vision evolved into a worldwide passion for evangelism, much of it involving athletics as the common denominator, spanning seven decades. Callan is also co-founder of Cedarville's Missions Involvement Service (MIS), now known as Global Outreach, in 1970 along with "PG," the late Pastor Harold Green.

Their ambition was the same as that of the current President, Thomas White. "Our desire was to have every student, faculty, and staff member experience what we'd experienced in evangelism," Callan said. "We wanted them to get out and see how the world really is, who the people are, how lost they are, and how Christ can change their lives. That was always the objective."

That desire alone has influenced scores of people.

Callan ventured out to East Asia with his own team during the summer of 1970. One of the members of that initial squad was Cedarville's current Vice President for Academics and Chief Academic Officer (Interim), Loren Reno '70.

A native of the village of Cedarville and a former Yellow Jacket on the hardwood, Reno is credited with actually coming up with the team's name, Athletes for Christ. "Loren is so special," said Callan. "I'm not sure that he didn't influence me more than I did him."

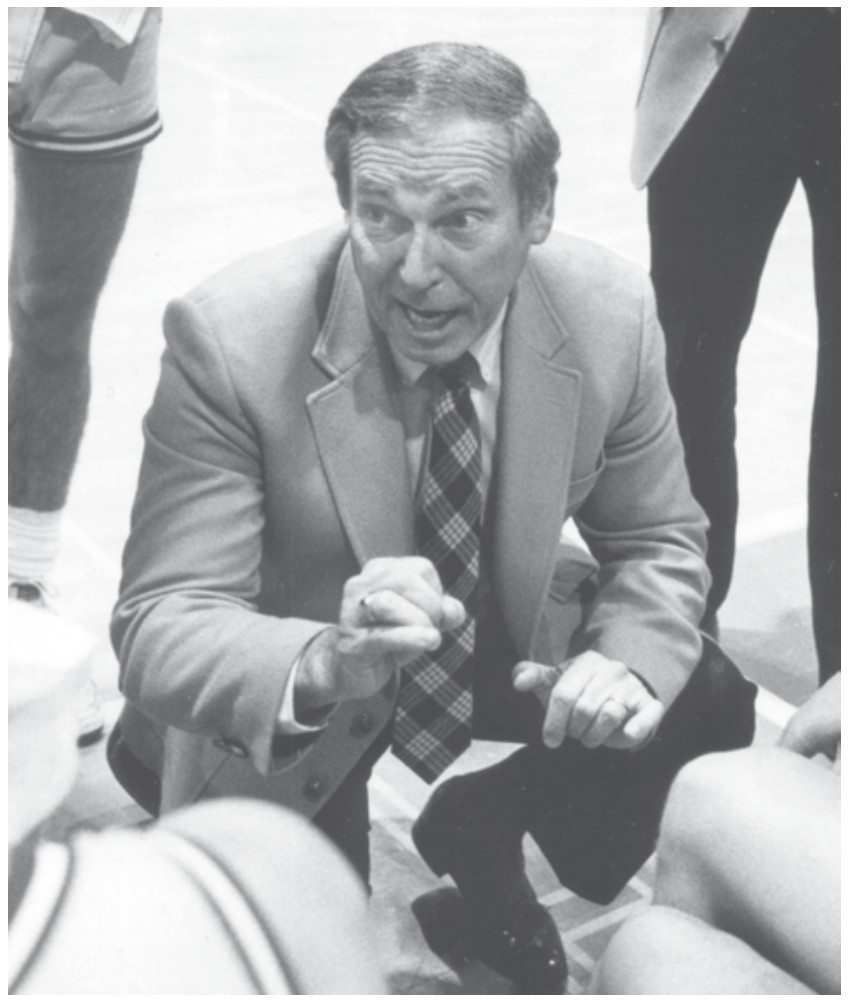

Reno has a different take.

"Coach Callan taught me much more than basketball. He taught me character, hard work, teamwork, and serving. He modeled all these along with a love for missions.

"Though 15 years his junior, I had trouble keeping up with Coach on and off the court, here at home, and on the missions field. Coach used basketball to teach about life and living for the Lord. He still 'coaches' many of us today."

Another local product and Cedarville grad, Tim Walker '99, has been the head men's basketball coach at Malone University since 2009. He added, "Outside of my father, no man has had a greater impact on my life. So much so that my wife and I named our youngest son 'Callan' to honor the legacy that Coach has had.

"Whether I am in coaching or any other field, I will always owe a great deal of my commitment to discipleship, local church ministry, and world missions to the impact that Don Callan has had on my life."

True "retirement" doesn't appear to be on the horizon. Coach and Brian Hanson '89 of GateKeepers Ministries continue their work locally with the Central State University football team and the Wilberforce University basketball teams, with many of the players coming to Christ.

God opened the door a few years ago in professional hockey with the old Dayton Gems. When the Lord closed it, He miraculously led them to become the chaplains of the NHL's Columbus Blue Jackets last season.

"I'm not spectacular, but I'm not bashful," Callan explained. "I'll talk to anyone. I've met leaders of countries, ambassadors, and I share the same message with them.

"I meet with the Senior Jackets at the fitness center on campus. Many of them don't know Christ as their personal Savior. I tell them the same stories that I've witnessed in my life and that God does spectacular things in spite of us."

Look at those titles again coach, missions leader, athletic director, professor, department chair, and dean - and, a godly example in every one of them.

Several years ago, I developed a short list of men who've influenced my life the most.

Coach Callan is on it.

Mark Womack '82 has been the Sports Information Director at Cedarville University since 1983. 